\title{
PROBLEMMING OF FORMATION OF LANDLINES OF TERRITORIAL COMMUNITIES IN THE CONDITIONS OF DECENTRALIZATION OF THE POWER
}

\author{
Priadka T., Ph.D., Associate Professor \\ National University of life and environmental Sciences of Ukraine, \\ E-mail:4436359@gmail.com \\ Drebot O.I. doctor of economics, professor, corresponding member of the Academy \\ of Agricultural Sciences, \\ Institute of Agroecology and Nature Management of the Academy of Agricultural \\ Sciences Ukraine. \\ E-mail:drebot_oksana@ukr.net
} Komarova N.V., assistant lecturer of land resources management and land cadastre E-mail: komarova_nv@ukr.net

One of the main tasks of the decentralization reform is to strengthen the role of territorial communities with the provision of their right to dispose of land, both within and outside settlements. The article analyzes the tendencies of decentralization of power in the Kyiv region.

Keywords. Decentralization of power, management of land resources, united territorial community, problems of modern land use.

\section{Problem statement.}

Ukraine is actively implementing reforms aimed at decentralization. These processes step by step provide a basis for the uniform development of territories and, ultimately, a successful country. One of the most important challenges of the present is the formation of capable territorial communities and effective self-governance.

The issue of decentralization of powers was reflected in the Concept of Reform of Local Self-Government and Territorial Organization of Power in Ukraine, approved by the Cabinet of Ministers of Ukraine Decree № 333 on April 1, 2014 [1]. It states that one of the urgent problems of the development of local self-government is to overcome its detachment from the solution of issues in the field of land relations. To solve it, it is proposed to provide local governments with basic level of authority in resolving development issues (land allocation, construction permits, acceptance into buildings), determining the material basis of local self-government property, in particular land owned by the territorial communities of villages, settlements, cities (communal property), and the proper tax base, as well as granting territorial communities the right to dispose of land resources within their territory, combine their assets and resources in cooperation 
of local communities to implement joint programs and effective provision of public services related communities.

To date local self-government bodies can engage issues of land relations, exclusively within the settlements. This system needs to be changed by transferring the basic right to dispose of land resources to local governments, territorial communities, and the state to retain the right to ensure control over the rational use of land resources.

\section{Analysis of recent research and publications.}

The issue of managing the land resources of the united territorial communities was studied by many Ukrainian land surveyors, among whom a significant contribution to the scientific achievements was made by such scientists as A. Tretyak, A. Martin, O. Dorosh, M. Khvesyk, B. Danylyshyn, I. Gorlenko, F. Zastavnyi, N. Zelins'ka, Ya. Pavlovich-Senet, A. Pavlyuk, S. Teleshun, O. Shablii and others.

Many experts and scholars point out that the Ukrainian government is characterized by a high degree of vertical centralization, and representative bodies on the ground have not become the leaders of an effective policy in the interests of mankind and the protection of the urgent needs of territorial communities. One of the main reasons for the low efficiency of local self-government activities is the lack of budget financing and the lack of a mechanism for transferring financial resources to the level of territorial communities.

\section{The aim of the study.}

Analyze the current situation regarding the formation of territorial communities in conditions of decentralization.
To substantiate the main tasks and directions for strengthening the role of land resources management by newly formed communities.

\section{Presenting main material.}

In the conditions of decentralization of power for Ukraine it is important to realize the key resource elements of the development of territorial communities. The goal of a voluntary association is to create capable communities that can ensure their development and take full responsibility for solving local problems. To do this, they must be formed according to the government methodology, to meet prospective plans for the formation of communities in the region. Only in this case, the law guarantees them the appropriate powers, and under them - financial and other resources.

The newly formed communities has a difficult situation in the use of land and other natural resources, first of all through [7]:

- underestimation of complexity and specificity of land reforms in the course of land and economic reforms in Ukraine;

- almost complete lack of information on land rights and other natural resources, their potential, state of use and protection in the territorial community;

- unsystematic and incompetent solutions to the tasks of land reform in the territories of local councils, in particular the removal of territorial communities from the disposal of land in their territory, the incompleteness of land reform and land use systems, especially in agriculture;

- unsatisfactory legislative and informational support and protection of property rights of rural residents to land and other natural resources; 
- ignoring the problems of introducing into the economic turnover of land as a capital, a resource-integrated approach to the development of rural territories in the process of transformation of land relations, the lack of a balanced state land policy regarding the planning of land use development and land management by territorial communities, mechanisms for its implementation;

- lack of consistent state policy on integrated land law development, holding and financing of state and municipal land management and land cadastre, formation of investment-attractive land use;

- extremely weak informational infrastructure of the land market and the lack of a well-balanced state policy for the formation and development of the land market for non-agricultural and agricultural purposes;

- lack of information provision of the rural population on the possibilities of using land and other natural resources in their territories in market conditions.

That is why the character and model of the spatial development of the combined territories, is determined by the main subjects of this development and the type of relations between them, which is determined by the goals. However, as noted in the Concept of Reforming Local Self-Government and Territorial Organization of Power in Ukraine, the system of local self-government does not currently meet the needs of society.

The functioning of local self-government in most of the territorial communities does not ensure the creation and maintenance of a favorable living environment necessary for the full development of a person, its self-realization, the protection of its rights, providing local governments, with organizations created by them, high-quality and accessible administrative, social and other services on the respective territories [5].
Today, the issue of land relations is controlled by local self-government only within settlements, which is only about $4 \%$ of Ukraine's territory. This system needs to be changed by transferring the bulk of land resources to the local governments, able territorial communities and giving over the rest to the state. The role of the state, first of all, will be to ensure control over the rational use of land resources [3].

To date, it is impossible to ensure the stable and effective development of territorial communities without giving them the opportunity to independently dispose of land resources [6]. Decentralization of land relations involves the transfer of the right to dispose of lands to communities, ownership of land will be transferred to united communities, the State Geocadaster will exercise only control over the use of land. Newly formed united communities should have economic resources for their effective development. In addition to budget and tax opportunities, the state transfers land resources to these communities[8].

As of the beginning of 2017, there were 366 united territorial communities in Ukraine that united 1740 local councils, in which the first local elections were held. These communities in 2017 switched to direct intergovernmental relations with the State Budget of Ukraine [9].

In 2017, following the adoption of a number of laws that resolved the problem issues of the association, the process of formation of united territorial communities received a new impetus to intensification. On April 30, 2017, the first local elections took place in 47 other united territorial communities. Thus, as of the end of October 2017, 413 united territorial communities were formed in Ukraine that united 5258 settlements, and in which the first elections of local self-governments took place. 


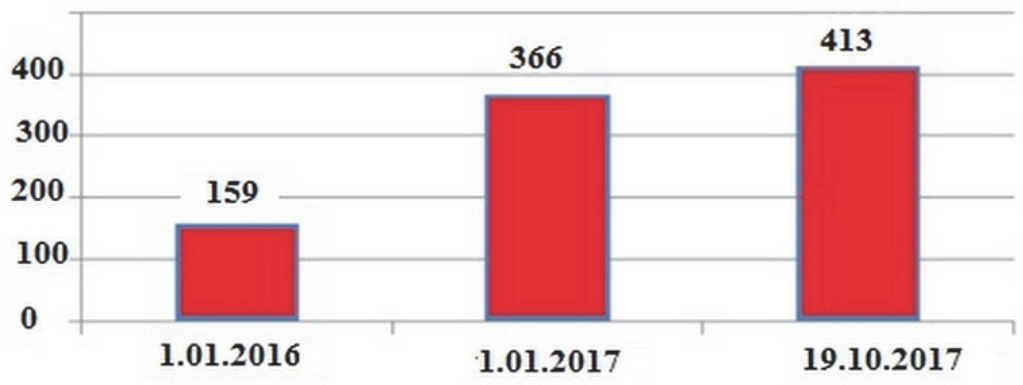

Pic. 1. The number of united territorial communities in the period from 2016 to 2017

According to the research and analysis of Pic. 2, it can be concluded that the decentralization of power and the creation of united territorial communities (UTCs) in the Kyiv region is most volatile.

Since the adoption of the Law on voluntary association of communities in the Kyiv region, the process has been artificially restrained by political instruments.

In 2 years only 2 united territorial communities were formed - Kalityans 'ka and Piskovs`ka.
More and more communities are willing to unite in order to have opportunities, prospects for development. But in many cases, it is not immediately possible to agree on the unification of efforts with all the neighboring communities for one or another reason. As a result, associations do not take place on a promising plan, and therefore communities will not receive the resources and powers that they have been counting on.

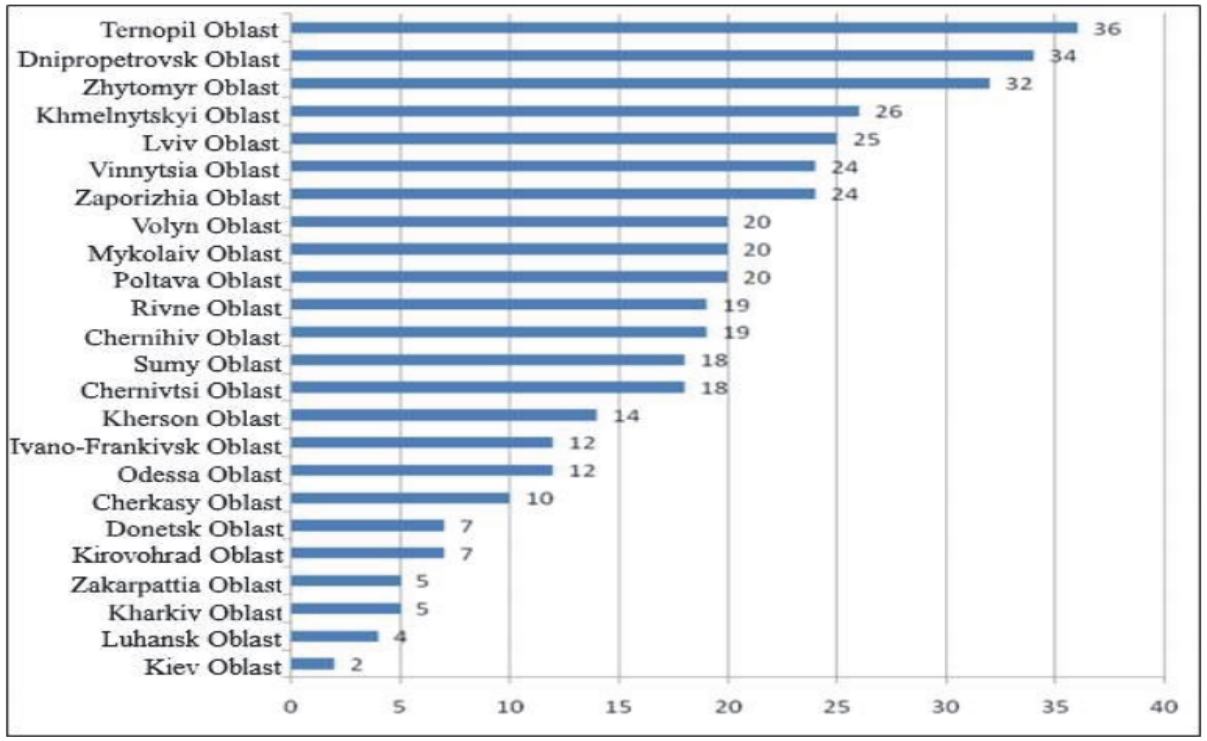

Pic.2. The number of united territorial communities by regions in October 2017 


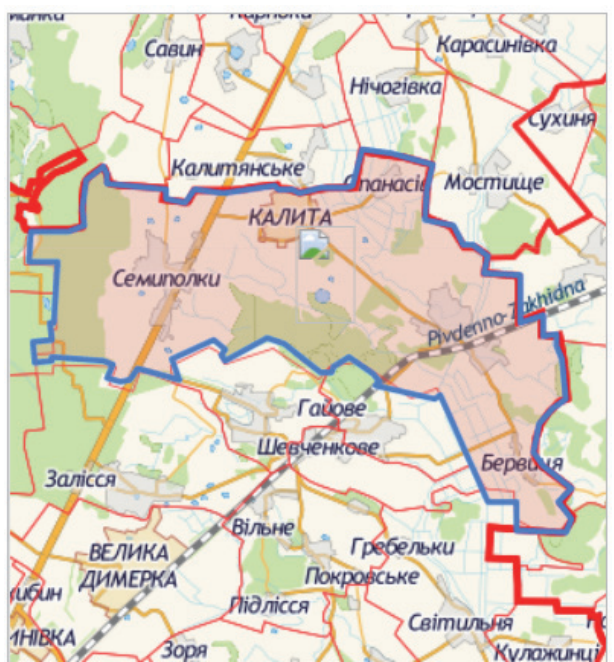

Pic. 3. Borders of Kalityans 'ka UTC

A new vision requires new approaches, namely the application of the mechanism of development of land resources management of the combined territorial communities as the basic basis for the spatial development of their territories. This involves identifying and specifying a set of tools and methods for implementing measures aimed at rational land use and protection of natural resources [2]. The development of this mechanism is a priority task and a basis for further actions in the direction of preservation and reproduction of land resources.

\section{Results of the research and their discussion.}

In our view, the mechanism for managing land resources, in the formation of territorial communities, should consist of economic, environmental and social factors.

This drawing gives an opportunity to determine the structure of the mechanism aimed at increasing investment

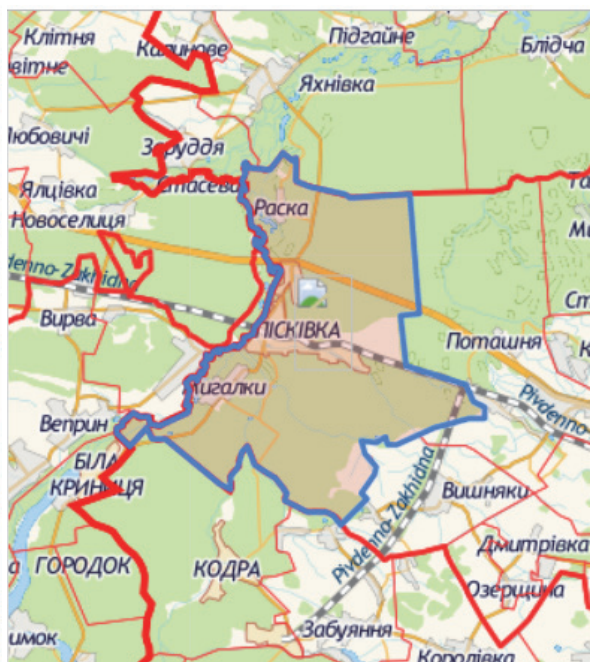

Pic. 4. Borders of Piskivs`ka UTC

attractiveness and efficiency of land use. The proposed structural scheme is not exhaustive, but insists on the need to define conceptual approaches to the formation and implementation of fundamental transformations to complete the land reform in Ukraine.

\section{Conclusions.}

Thus, in order to achieve effective land management of territorial communities, in a decentralized environment, it is necessary to improve the system of distribution of powers of state authorities, search for ways to combine interactions of power and business in the newest economic conditions. In the newest economic conditions, the development of territorial management is no longer limited to two coordinates, but is considered in three-dimensional space, where development is the development of a sequence of events in most cases and decisions that are considered in a combination of economic, environmental and social components. 


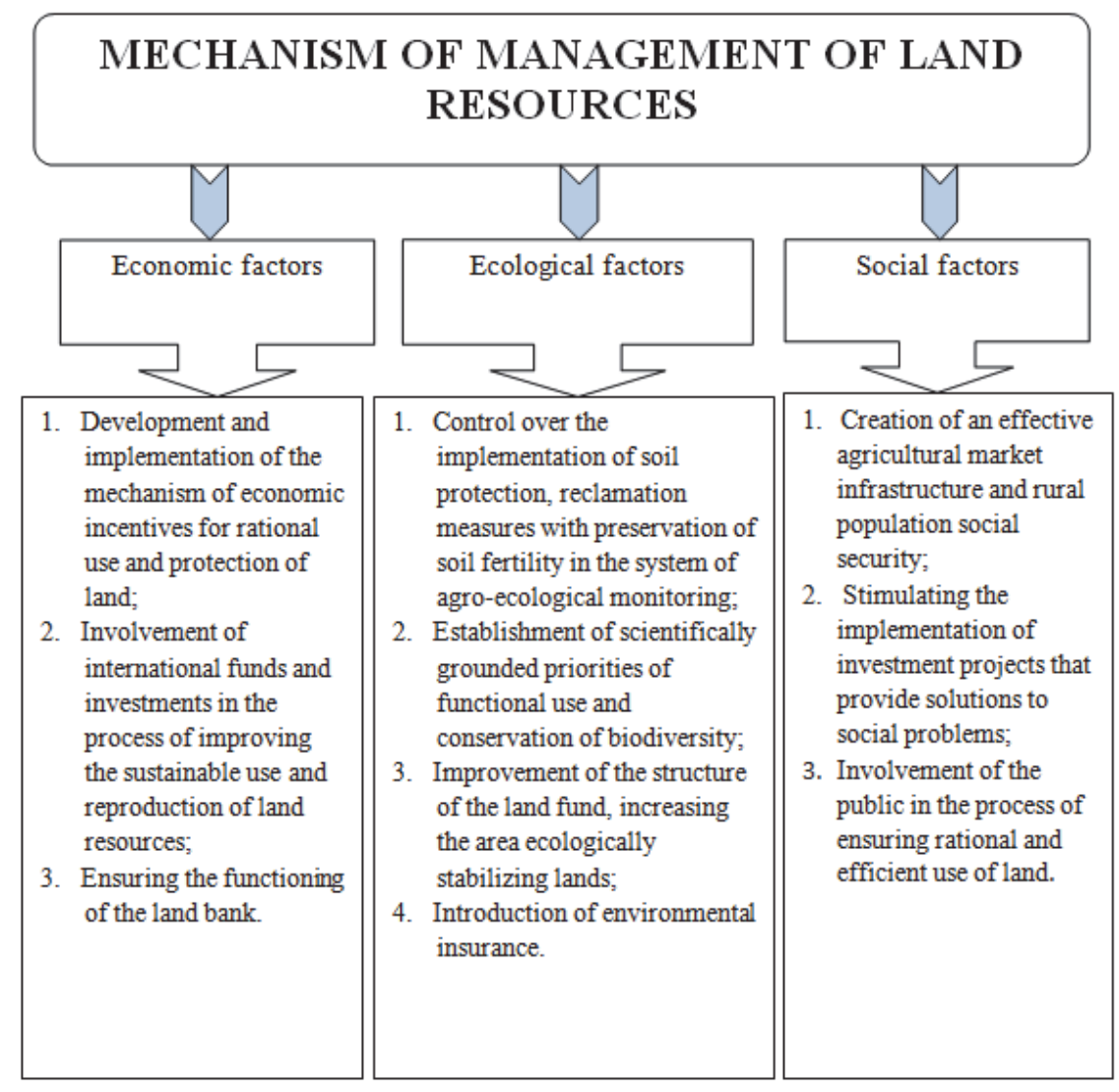

Source: Developed by authors

\section{Pic.5. Mechanism of Land Resources Management in the Formation of Territorial Communities}

\section{References:}

1. Pro skhvalennia Kontseptsii reformuvannia mistsevoho samovriaduvannia ta terytorialnoi orhanizatsii vlady v Ukraini: Postanova Kabinetu Ministriv Ukrainy vid 01 kvitnia 2014 roku №333-r. - Rezhym dostupu : http://zakon4.rada.gov.ua/ laws/show/333-2014- \%D1\%80.

2. Sh.I. Ibatullin, O.V. Stepenko, O.V. Sakal Mekhanizmy upravlinnia zemelnymy vidnosynamy $v$ konteksti zabezpechennia staloho rozvytku/ Sh.I. Ibatullin, O.V. Stepenko, O.V. Sakal [ta inshi]. - K.: Derzhavna ustanova
«Instytut ekonomiky pryrodokorystuvannia ta staloho rozvytku Natsionalnoi akademii nauk Ukrainy", 2012. $-52 \mathrm{~s}$.

3. Dorosh O. Orhanizatsiino-instytutsionalne zabezpechennia terytorialnoho planuvannia zemlekorystuvannia silskykh terytorii / O. Dorosh // Ekonomist. - 2015. - № 8. -S. 22-25. - Rezhym dostupu: http://nbuv.gov. ua/UJRN/econ_2015_8_7.

4. Tretiak A.M. Zemelnyi kapital: teoretyko-metodolohichni osnovy formuvannia ta funktsionuvannia : monohrafiia / A.M. Tretiak. - Lviv : Vyd-vo "Spolom», 2011. $-520 \mathrm{~s}$. 
5. Dobriak D.S. Ekoloho-ekonomichni zasady formuvannia zemlekorystuvannia $v$ rynkovykh umovakh / D.S. Dobriak, D.I. Babmindra. - K. : Urozhai, 2010. - 334s.

6. Tretiak A.M. Kontseptualni zasady rozvytku v Ukraini suchasnoi bahatofunktsionalnoi systemy upravlinnia zemelnymy resursamy / A.M. Tretiak, R.M. Kuryltsiv, N.A. Tretiak // Zemlevporiadnyi visnyk. - 2013. - № 9. - S. 25-8.

7. A.M. Tretiak, V.M. Tretiak, T.M. Priadka, N.A. Tretiak Terytorialne planuvannia zemlekorystuvannia $\mathrm{v}$ konteksti formuvannia finansovoi stiikosti obiednanykh terytorialnykh hromad/ A.M. Tretiak, V.M. Tretiak, T.M. Priadka, N.A. Tretiak //Zemleustrii, kadastr i monitorynh zemel. - 2017. - № 1. - S. 21-27. - Rezhym dostupu:http://nbuv.gov. ua/UJRN/Zemleustriy_2017_1_6.

8. Priadka T. M., Korbut T. S. Naukovi aspekty orhanizatsii terytorialnoho planuvannia na suchasnomu etapi rozvytku zemelnykh vidnosyn / T.M. Priadka, T. S. Korbut // Innovatsiinv ekonomika. - 2012. - № 9. - S. 146-148.

9. Detsentralizatsiia na vlasnomu dosvidi: v yakykh rehionakh naibilsh pozytyvno otsiniuiut reformu? / Sait Natsionalnoi rady reform [Elektronnyi resurs] - Rezhym dostupu: http://reforms.in.ua/ua/novyna/decentralizaciya-na-vlasnomu-dosvidi-v-yakyh-regionah-naybilshpozytyvno-ocinyuyut-reformu

\section{***}

Дребот О.І., Прядка Т.М., Комарова Н.В.

ПРОБЛЕМАТИКА УПРАВЛІННЯ ЗЕМЕЛЬНИМИ РЕСУРСАМИ ПРИ ФОРМУ-
ВАННІ ТЕРИТОРІАЛЬНИХ ГРОМАД В УМОВАХ ДЕЦЕНТРАЛІЗАЦІЇ ВЛАДИ

Одним із основних завдань реформи децентралізації $\epsilon$ посилення ролі територіальних громад із наданням ім права самим розпоряджатися землями, котрі перебувають як у межах населених пунктів, так і поза ними. у статmі досліджено тенденції розвитку децентралізації влади у Київській області.

Ключові слова: Децентралізація влади, управління земельними ресурсами, об'єднана територіальна громада, проблематика сучасного землекористування.

\section{Дребот О.И., Прядка Т.М., Комарова Н.В.}

ПРОБЛЕМАТИКА УПРАВЛЕНИЯ ЗЕМЕЛЬНЫМИ РЕСУРСАМИ ПРИ ФОРМИРОВАНИИ ТЕРРИТОРИАЛЬНЫХ ОБЩИН В УСЛОВИЯХ ДЕЦЕНТРАЛИЗАЦИИ ВЛАСТИ

Одной из основныХ задач реформы децентрализации является усиление роли территориальных общин с предоставлением им права самим распоряжаться землями, которые находятся как в пределах населенных пунктов, так и вне их. В статье исследованы тенденции развития децентрализации власти в Киевской области.

Ключевые слова: Децентрализачия власти, управления земельными ресурсами, объединенная территориальная община, проблематика современного землепользования. 